\title{
Carl-Mario Sultana
}

University of Malta

\section{Catechesis and its Six Tasks}

\begin{abstract}
The aim of catechesis is not simply to give information to interlocutors about the Catholic faith. Catechesis seeks to do much more than this, with its ultimate aim being that of putting the human being in communion with Christ. This is achieved through the six tasks of catechesis which need to be deeply embedded in human experiences. The six tasks through which catechesis seeks to achieve its endeavours include: knowledge of the faith, liturgical education, moral formation, formation in prayer and methods of prayer, education for community life and missionary initiation.
\end{abstract}

\section{Keywords}

Communion with Christ, Formation, Human Experience, Knowledge of the Faith, Tasks of Catechesis.

\section{Introduction}

Pope Paul VI in Evangelii Nuntiandi vehemently insisted that the Church exists to evangelise. ${ }^{1}$ There is no other reason for which the Church exists in the world. This fundamental mission of the Church was lately re-iterated both

${ }^{1}$ Cfr. Pope Paul VI, Evangelii Nuntiandi (8 ${ }^{\text {th }}$ December 1975), http://w2.vatican.va/content/ paul-vi/en/apost_exhortations/documents/hf_p-vi_exh_19751208_evangelii-nuntiandi.html (19.09.2017), para. 14. 
by Pope Benedict ${ }^{2}$ and by Pope Francis. ${ }^{3}$ This mission of evangelisation can be accomplished in many ways: "through witness and proclamation, word and sacrament, interior change and social transformation."

One of the privileged ways in which the evangelisation mission of the Church is actually carried out in practice is through the process of catechesis. ${ }^{5}$ All the different forms of catechesis which are carried out within the Church have this particular aim: the evangelisation of peoples, that is, the bringing of the Good News to individuals wherever they stand. This is not to be reduced only as the evangelisation ad gentes as was thought before Vatican Council II, that is, as the bringing of the Good News to those who have never encountered or heard about Christ. Catechesis serves the evangelisation mission of the Church by deepening the faith which the individual would supposedly already have embraced through the first proclamation. ${ }^{6}$

As a process, catechesis has a specific objective: that of helping the individual enter into a special relationship with Christ. ${ }^{7}$ This is a very specific objective which may very easily become blurred or at times even remain unrealized due to the emphasis which different catechists make on different aspects during the process of catechesis. When we have catechists who overemphasise the importance of the contents of the faith at the expense of a truly human experience during the process of catechesis, we risk that the interlocutors do not actually enter into communion and intimacy with Christ. They may know a lot of information about Christ and the Christian way of living but they will lack the most important thing: a personal relationship with Christ.

${ }^{2}$ Cfr. Pope Benedict XVI, Angelus - Sunday 24th October 2010, http://w2.vatican. va/content/benedict-xvi/en/angelus/2010/documents/hf_ben-xvi_ang_20101024.html (21.09.2017).

${ }^{3}$ Cfr. Pope Francis, Address to the Members of the Representative Council and Personnel of "Caritas Internationalis" - $17^{\text {th }}$ November 2016, http://w2.vatican.va/content/francesco/en/ speeches/2016/november/documents/papa-francesco_20161117_caritas-internationalis.html (21.09.2017).

${ }^{4}$ Congregation for the Clergy, General Directory for Catechesis (15 ${ }^{\text {th }}$ August 1997), http://www.vatican.va/roman_curia/congregations/cclergy/documents/rc_con_ccatheduc_ doc_17041998_directory-for-catechesis_en.html (21.09.2017), para. 46.

${ }^{5}$ Cfr. General Directory for Catechesis, para. 63-64.

${ }^{6}$ Cfr. General Directory for Catechesis, para. 60-72.

${ }^{7}$ Cfr. General Directory for Catechesis, para. 80-83. 
The objective of catechesis - a personal relationship with Christ - can be met in a truly adequate and authentic way through the six tasks of catechesis. These six tasks of catechesis are: promoting knowledge of the faith, liturgical education, moral formation, teaching how to pray, education for life in the community, and missionary initiation. ${ }^{8}$

Many consider these tasks of catechesis simply as different ways to get to the same objective. However, reality shows us that these tasks though different are complementary. They must be seen as a whole and all are necessary for a balanced and truly complete vision of Christianity as a whole. How can one live a truly Christian life if one is not aware that Christianity is centred around community life as well? This demonstrates that each one of these six tasks of catechesis is interdependent on the others. Notwithstanding this, we must also note that each of these tasks realises the object of catechesis in its own way. Each one of them helps the individual to encounter Christ and enter into a personal relationship with Christ in a particular way. The General Catechetical Directory (1971) and the General Directory for Catechesis (1997) both emphasise that "it is very important that catechesis retain the richness of these various aspects in such a way that one aspect is not separated from the rest to the detriment of the others."

A particularly fundamental aspect of these tasks is that they must all be deeply rooted in human experience. ${ }^{10}$ Were they not to be so, they would only be simple knowledge or words which would not lead to a positive change in the life of the individual which is a result of the personal encounter with Jesus Christ. ${ }^{11}$

\section{Human Experience}

Human experience is fundamental when we speak about catechesis as a vehicle for evangelisation. In fact, human experience is the foundation of any other

${ }^{8}$ Cfr. General Directory for Catechesis, para. 85-86.

9 Sacred Congregation for the Clergy, General Catechetical Directory (11 $1^{\text {th }}$ April 1971), http://www.vatican.va/roman_curia/congregations/cclergy/documents/rc_con_cclergy_ doc_11041971_gcat_en.html (23.09.2017), para. 31; General Directory for Catechesis, para. 87.

${ }^{10}$ Cfr. M. K. Glavich, The Six Tasks of Catechesis. Key Principles and Practices for Forming Faith, New London 2016, Twenty-Third Publications, p. 5.

${ }^{11}$ Cfr. General Directory for Catechesis, para. 87. 
form of spiritual or religious experience. ${ }^{12}$ Notwithstanding this, there are many misconceptions of what constitutes a human experience. Some people think that a human experience simply constitutes an event in which one is present, and which one lives or goes through in some way or another. This is insufficient as a human experience, since a truly human experience is made up of three constitutive parts without which one cannot call an event an experience.

The three elements which are sine qua non for an event to be considered an experience are:

1. A lived reality or situation

2. A reflection and interpretation of the situation

3. An appropriation of the meaning and its eventual expression in a personal way. ${ }^{13}$

A human experience always starts from a lived reality or event. If one does not have a primary event or happening, one can never speak of an experience. Moreover, one needs to live the particular event or reality in a significant way, that is, by living the event in a deep way, and not just on the outskirts or on the periphery. This is what constitutes the starting point of any experience.

The second step which is necessary to qualify an event as a truly human experience is the fact that it is not enough to simply live an event or undergo a particular lived situation. One also needs to stop to think and reflect on the particular event which one has gone through. Therefore, the lived event or reality is not simply endured or gone through in a passive manner, but it is reflected upon, and its significance for the life of the individual is extracted in a very clear and unambiguous way. This forms the basis of the third step which is necessary to have a truly complete human experience.

Once the event has been lived in a complete and global way, and then reflected upon, it will be much easier to appropriate its meaning and make it one's own. This will ultimately help the individual who underwent that experience to express its significance in one's life. It is only in this way that the fruit of that lived experience is expressed in a unique way in one's daily life in a personal way. There is no other way in which one can demonstrate the effects of a human experience in a more tangible way.

${ }^{12}$ Cfr. General Directory for Catechesis, para. 116-117.

${ }^{13}$ Cfr. E. Alberich, La catechesi oggi. Manuale di catechetica fondamentale, Leumann (Torino) 2001, Elledici, p. 108-110; E. Alberich, J. Vallabaraj, Communicating a Faith that Transforms. A Handbook of Fundamental Catechetics, Bangalore 2004, Kristu Jyoti Publications, p. 103-105. 
What makes a truly human experience is also at the basis of a religious experience. The same procedure of a human experience in three stages needs to be followed in order to have an authentic religious experience. The only difference is the depth in which the experience is analysed and reflected upon. The depth in which a religious experience is analysed is such that when the human being tries to find an interpretation for some events, one does not find a satisfactory answer when relying only on a human interpretation. This necessarily opens the individual to the Transcendent. This is the new dimension and criterion for interpreting human events, and which gives them a much deeper meaning which would have never been achieved in an intelligible way had they been interpreted only on the human level. ${ }^{14}$

A particularly illuminating example is the case of the death of a loved person. There is a total difference between the way such an event is interpreted by an atheist and a Catholic. Whilst for the atheist, physical death means the end of life on earth with all the little significance which one would have acquired during life, for the Catholic, death means only the end of life on earth. It also means the beginning of a never-ending life where one gathers and enjoys the fruit of what has been sown in life on earth. This does not mean that for the Catholic believer death ceases to be painful due to the loss. It still remains painful, but does not mean the end of all. So, while for the non-believer and the atheist, the idea of death may lead the person to frustration and despair, for the Catholic it means a change of life from one state to another where one enjoys the fruit of one's endeavours. This Catholic interpretation is arrived at when one considers God's actions of salvation towards the human being when interpreting death as an event in the life of the human being.

\section{Promoting Knowledge of the Faith}

Having outlined and highlighted the importance of human experience in the process of catechesis and of the education for the faith, we can now delve deeper into each of the six tasks through which catechesis attempts at reaching its objective of helping the individual enter into communion with Christ as a person. ${ }^{15}$

\footnotetext{
${ }^{14}$ Cfr. La catechesi oggi, p. 110-113; Communicating a Faith that Transforms, p. 105-108.

${ }^{15}$ Cfr. Catechism of the Catholic Church, http://www.vatican.va/archive/ENG0015/_INDEX. HTM (29.09.2017), para. 426.
} 
The first things that comes to mind had we to go out into the street and ask people what their opinion about catechesis is through a vox-pop, and what catechesis aims at doing, many would surely respond that catechesis is aimed at giving knowledge and information about the Catholic faith. This is true to a certain extent. However, it would be detrimental to catechesis had it to be confined solely to simply giving knowledge about the faith. Whoever tries to give only the raw teachings will be trying to transmit something which cannot be sustained by itself because it can never be attractive and relevant to the interlocutors. Simply transmitting doctrinal formulae does not mean that people will be able to put them into practice. This was the problem with the Traditional Method of catechesis in the form of a question and answer. ${ }^{16}$

On a human level, if one seeks to encounter and enter into a relationship with someone else, the first thing which is necessary is to get to know the other person well, his/her likes and dislikes, his/her interests and hobbies. ${ }^{17}$ This would surely help both of the individuals concerned to get to know each other better and to be able to encounter each other where they actually stand. This is also true for catechesis. The person who found Christ seeks to get to know him better, and thus enter into a mutual relationship with him in a serious way. ${ }^{18}$ This implies that the catechist must have a very deep relationship with Christ for an effective ministry and to be able to help others enter into a relationship with Christ.

However, one must keep in mind that our catechesis will be lacking much had we to confine the process of catechesis only to the simple handing on of knowledge and of doctrine. Catechesis is aimed at augmenting the encounter of the individual with Christ himself as a living person and who constitutes the Good News. Pope Francis in Evangelii Gaudium clearly explains that "there can be no true evangelization without the explicit proclamation of Jesus as Lord"19. If in catechetical meetings, the interlocutors are not helped to encounter Christ

${ }^{16}$ Cfr. C. M. Sultana, Catechesis in Europe during the 20th Century, in: G. Bonney, R. Vicent (eds.), Sophia - Paideia. Sapienza e educazione (Sir 1, 27). Miscellanea di studi offerti in onore del prof. Mario Cimosa, Roma 2012, LAS, p. 423-425.

17 Cfr. The Six Tasks of Catechesis, p. 11.

18 Cfr. General Directory for Catechesis, para. 87.

19 Pope Francis, Evangelii Gaudium (24 ${ }^{\text {th }}$ November 2013), http://w2.vatican.va/content/ francesco/en/apost_exhortations/documents/papa-francesco_esortazione-ap_20131124_ evangelii-gaudium.html (5.10.2017), para. 110. 
as a person in a direct way, we will surely be losing a lot of opportunities. It is when the contemporary human being encounters Christ that s/he can declare his/her faith in Christ as the Lord. After all, we have to admit that it is when the human being proclaims that Christ is the Lord that s/he can then live the same life-style of Christ as this is found in the Gospels.

When speaking about catechesis as the imparting of knowledge of the faith, we cannot forego the importance of the Bible. This is primarily due to the fact that all the faith is based on the Word of God in the Bible and in Tradition. This is why the Bible is considered as one of the sources of catechesis. ${ }^{20}$ One of the last instructions which Jesus gave to his disciples before ascending to heaven was: "Go therefore and make disciples of all nations, baptizing them in the name of the Father and of the Son and of the Holy Spirit, and teaching them to obey everything that I have commanded you" (Mt 28, 19-20). This deposit of experiences and of teachings of Christ to his disciples can be found in the Word of God.

Moreover, when speaking about knowledge of the faith as one of the tasks of catechesis, we need to keep in mind both the content and the method. One of the modern-day pitfalls of catechesis is trying to pass on the message of Christ without helping the interlocutors to come into direct and intimate contact with the Gospels. ${ }^{21}$ This is usually the result when one is 'enslaved' in using a particular method no-matter-what. In over-concentrating on the method, one will be forgetting the message!

This is where the Bible as the Word of God comes in. For many decades, the Word of God as a source of light for the life of the faith has been neglected. ${ }^{22}$ As from Vatican Council II, the Bible as the Word of God which sheds light on the life of the human being has been re-adopted. While using modern didactic techniques to transmit the message to the contemporary human being, we still cannot ignore the central part of catechesis, which is the message itself. If we try to evangelise other people without handing them the Gospels as the message, we will be giving them a message which has been emptied from its

${ }^{20}$ Cfr. La catechesis oggi, p. 81-107, 118-119; Communicating a Faith that Transforms, p. 77-102, 114-116; C. Bissoli, Va' e annuncia (Mc 5, 19). Manuale di catechesi biblica, Leumann (Torino) 2006, Elledici, p. 91-143.

${ }^{21}$ Cfr. The Six Tasks of Catechesis, p. 23.

${ }^{22}$ Cfr. Va' e annuncia, p. 25-53. 
intrinsic value. In this respect, the General Directory for Catechesis speaks of the principle of 'fidelity to God and fidelity to the human person.. ${ }^{23}$

One of the best ways in which the Bible in general and the Gospels in particular can be used in the process of catechesis is by reading, interpreting and reflecting on particular texts which demonstrate the way in which God, through Jesus Christ, entered into the history of the human being in order to change it intrinsically into something positive. Jesus entered into a relationship with human beings in order to demonstrate God's love, friendship and willingness to save them. In catechesis, the Gospels need to be proclaimed in the same way in which the Gospels proclaim the Good News, that is, by narrating the stories of people who met Jesus and were able to change their life as a result of this encounter. ${ }^{24}$

The use of the Bible in catechesis brings to mind the Kerygmatic Method which was the prevalent method used in catechesis in Europe as from the 1930's to Vatican Council II, when the anthropological method was then introduced. The Kerygmatic Method was based on the Word of God as the Good News of salvation, putting Christ and the Paschal Mystery at the very centre and as the fulcrum of all catechesis. ${ }^{25} \mathrm{Had}$ we to apply this method today, the results would not be as favourable as they were when it was first proposed as a method for catechesis. Nonetheless, we can still learn a lot from it. The idea of Christ as the mid-point of all our knowledge of the faith is very important since through Christ, all other things fall into their correct position. With Christ as the point of reference, the hierarchy of truths is respected in its integrity and with respect to what takes priority as the most important and what is secondary. ${ }^{26}$

The use of the Bible together with an imparting of knowledge about the faith is not enough to induce somebody to live the faith. The witness which the catechist bears to what $\mathrm{s} / \mathrm{he}$ proclaims and which is lived in daily life is also

${ }^{23}$ Cfr. General Directory for Catechesis, para. 145, 149.

${ }^{24}$ The document of the Pontifical Biblical Commission entitled The Interpretation of the Bible in the Church gives us the hermeneutical criteria to embark on such an exercise. See Pontifical Biblical Commission, The Interpretation of the Bible in the Church (15th April 1993), https://www.ewtn.com/library/curia/pbcinter.htm (6.10.2017).

${ }^{25}$ Cfr. Catechesis in Europe during the 20th Century, 426-430; G. Biancardi, U. Gianetto, Storia della catechesi. 4. Il movimento catechistico, Roma 2016, LAS, p. 201-215.

${ }^{26}$ Cfr. General Directory for Catechesis, para. 114-115; La catechesi oggi, p. 153-154; Communicating a Faith that Transforms, p. 143-145; The Six Tasks of Catechesis, p. 13. 
of utmost importance. ${ }^{27} \mathrm{~A}$ catechist who sees his/her ministry as simply imparting knowledge and a series of formulae to the interlocutors leaves much to be desired in the effectiveness of what catechesis attempts at achieving. If our aim is to evangelise and to bring the contemporary human being into a direct relationship with Jesus, we need to continue using the same method which Jesus used: acting before proclaiming. The ministry of the catechist is fecund if the words proclaimed are preceded by witness, that is, by a way of life which truly demonstrates that $\mathrm{s} /$ he not only knows about the faith, but truly lives its implications in daily life. ${ }^{28}$

The fact that most of the catechists in our times are lay people, bears a lot of weight in our contemporary society. The reason for this is that catechists, being lay people, can infiltrate more in society and in the daily lives of people. They go to work daily, live a normal life in their families, thus through their witness show that it is possible to live the Gospel in today's world. However, this can be achieved when those involved in the ministry of catechesis live the Gospel values as leaven in our contemporary world. ${ }^{29}$

A sound catechesis which transmits knowledge of the faith should not only be given to those being initiated into the faith but should also be the backbone of the catechesis imparted to all those who have already embraced the faith. A good knowledge of the faith, together with its correct interpretation and application is necessary throughout one's life. It is only through this that we can ensure that the faith is lived in all the different seasons of one's life. ${ }^{30}$

The task of catechesis which aims at imparting knowledge of the faith is not an isolated task. It actively opens to us the way of the other tasks of catechesis, since all are in some way or another related to it since knowledge and information is at the basis of them. ${ }^{31}$

${ }^{27}$ Cfr. General Directory for Catechesis, para. 156-157; La catechesi oggi, p. 295-296; Communicating a Faith that Transforms, p. 287-289.

${ }^{28}$ Cfr. Congregation for the Evangelization of Peoples, Guide for Catechists. Document of Vocational, Formative and Promotional Orientation of Catechists in the Territories Dependent on the Congregation for the Evangelization of Peoples ( ${ }^{\text {rd }}$ December 1993), http://www.vatican. va/roman_curia/congregations/cevang/documents/rc_con_cevang_doc_19971203_cath_ en.html (10.10.2017), para. 3-7.

${ }^{29}$ Cfr. W. E. Biernatzki, Catholic Communication Research. Topics and a Rationale, London 1978, The Research Facilitator Unit for Social Communication.

${ }^{30}$ Cfr. The Six Tasks of Catechesis, p. 14.

${ }^{31}$ Cfr. The Six Tasks of Catechesis, p. 11. 


\section{Liturgical Education}

Vatican Council II's Constitution on the Liturgy - Sacrosanctum Concilium posits that one of the aims of the Council was to empower the faithful to live a more vigorous Christian life. One of the ways in which this was to be done was through the reform of the liturgy which was also to be accompanied by a more ardent catechesis and formation on the liturgy. This was not only to be reserved to priests in their formation in seminaries, but also to the lay faithful who seek to participate fully in the liturgy. ${ }^{32}$ This demonstrates that liturgical education should form an integral part of any catechesis.

The way in which catechesis attempts at imparting a liturgical education is two-fold. Both catechesis and the liturgy require each other if they are to develop in a harmonious way. The liturgy requires catechesis in that catechesis aims at helping the believer to understand the rites and the forms used in the liturgy. Any symbolic action loses a part of its effect if it is not clearly explained. This is more so for the Sacraments through which grace is imparted onto the believing community which celebrates and receives them. ${ }^{33}$

Catechesis helps the individual to enter into the level of mystery which the rites stand for. This in its turn leads to an active participation. This was something which Vatican Council II earnestly desired. ${ }^{34}$ This active participation in the liturgy cannot be achieved if the individual does not understand the prayers and the rites used during the liturgy. This is something which catechesis can give through a process of thorough formation. Catechesis also introduces the person to the attitudes which are necessary if the individual seeks to live in communion and in a responsible way with others, while demonstrating a sense of gratitude to God. It is only when one understands the meaning of symbols and words, even if in a very limited way, that one can renew one's life by living the implications of the liturgical symbols in one's life. Symbols which mean nothing or which are divested of their deep meaning leave no impact on the contemporary human being. ${ }^{35}$

${ }^{32}$ Cfr Vatican Council II, Constitution on the Sacred Liturgy Sacrosanctum Concilium ( $^{\text {th }}$ December 1963), http://www.vatican.va/archive/hist_councils/ii_vatican_council/documents/ vat-ii_const_19631204_sacrosanctum-concilium_en.html (11.10.2017), para. 1, 17, 105.

${ }^{33}$ Cfr. La catechesi oggi, p. 267-268; Communicating a Faith that Transforms, p. 252-253.

${ }^{34}$ Cfr. Sacrosanctum Concilium, para. 11, 14-20.

${ }^{35}$ Cfr. La catechesi oggi, p. 267-268; Communicating a Faith that Transforms, p. 252-253. 
A liturgical education can be imparted during several moments of the liturgical celebration. To mention a few, we can speak of the catechetical value of the liturgy:

1. in the Liturgy of the Word where God enters into dialogue with human beings;

2. in preaching, especially through the homily;

3. in the most important prayers during the celebration of all the Sacraments, each in a different way;

4. in itineraries and passages, especially in the Rite of Christian Initiation.

However, we must not be alluded that this comes about automatically. A truly liturgical catechesis is necessary for the contemporary human being to enter into the mystery celebrated in the liturgy. ${ }^{36}$

Notwithstanding this close relationship in which the liturgy needs catechesis in order to achieve its full potential, the relationship is not one way: catechesis needs the liturgy. It is in the liturgy that catechesis finds a source of inspiration for particular moments of catechesis. Here Advent, Lent, Christmas Time and Easter Time come to mind. The liturgical calendar with its different times and celebrations provides catechesis with privileged moments in which a sound catechesis helps the faithful to understand that particular time better and to live the kairos of that particular time to the full. In this sense, the liturgy acts as a sign of the time which catechesis can elaborate upon and explain.

Liturgical education is also achieved through occasional catechesis. Occasional catechesis can take several forms, ranging from catechesis in preparation for the reception of a Sacrament to catechesis in preparation for a particular event, such as a particular anniversary in a local Church. Occasional catechesis in preparation for a sacrament usually takes the form of preparatory meetings in view of the celebration and administration of the particular Sacrament. This should not be reduced to the simple explanation of the rubric in the administration of the Sacrament, and to the step by step procedure of how the Sacrament is celebrated, but should also include a deep catechesis on the mystery which is celebrated in and through that particular sacrament. Occasional catechesis also helps the persons who will be celebrating the Sacrament to be more conscious of the latent effects which the Sacrament leaves on the life of the person receiving it and of the way one is now called to live once s/he receives the sacrament.

${ }^{36}$ Cfr. La catechesi oggi, p. 265-267; Communicating a Faith that Transforms, p. 250-251. 


\section{Teaching Prayer}

In seeking to give a sound liturgical education to the faithful, catechesis cannot do without teaching the People of God on how to pray. There are many different facets to the task of catechesis in teaching someone how to pray. When considering this task one thinks immediately on the prayers one should know in order to be able to pray in a verbal way. However, this is not enough. Catechesis needs to introduce the person to prayer, and especially to the attitudes which are required for a truly fruitful relationship with God through prayer. ${ }^{37}$

The first thing that may come into the mind of a catechist when trying to unravel what the ministry of catechesis seeks to do with regards to prayer is to ask about which prayers the Christian should know. This is a legitimate question but a catechist who sees his/her ministry as simply teaching prayers off by heart to the interlocutors is missing a very important aspect of prayer. Prayer is not simply the recitation of formulae learnt off by heart; it is a deep and intimate relationship with God which is not simply achieved through lip service.

The idea of teaching prayers by heart may put some people off, especially those who are allergic to memorization in catechesis. This point merits some more elaboration. Those who advocate against all forms of memorization, even of simple prayers, posit that memorization can be dangerous due to the temptation to render praying a simple lip recitation of prayer, without even trying to enter into a true relationship with God. Whilst this stance is a true risk, we cannot do without memorization especially of the most basic prayers and of liturgical prayers which are celebrated in common. At the end, the baggage which every individual carries home after a long process of catechesis is usually made up of such prayers learnt by heart, and which when recited in common help to create a non-distractive prayerful atmosphere since all pray in unison. Still, rote learning should be avoided as much as possible. ${ }^{38}$

The contemporary human being who seeks to live a Christian life to the full needs to know how to pray in order to form his/her spirituality. Spirituality is so necessary in our contemporary society where we have a continually growing number of individuals who claim that they believe, but at the same time do not actually know what they believe in. This state of affairs should not discourage us, but it must empower us more to give a true induction to prayer in our catechesis.

${ }^{37}$ Cfr. The Six Tasks of Catechesis, p. 47.

${ }^{38}$ Cfr. La catechesi oggi, p. 154-155; Communicating a Faith that Transforms, p. 145; The Six Tasks of Catechesis, p. 51. 
Teaching prayer though catechesis thus also entails helping our interlocutors to experience different kinds of prayer: vocal and mental, formulas, spontaneous prayer and even liturgical prayer. ${ }^{39}$ We can help our interlocutors experience prayer in its different forms: blessing and adoration, petition, intercession, thanksgiving and praise. ${ }^{40}$ This is one of the ways in which catechesis and human experience cross each other. However, these different forms of prayer would leave little effect on the individual if the different attitudes with which the Catholic believer should enter into prayer do not also form part of our catechesis.

In prayer, an attitude of humility is necessary together with openness to God and to the ways in which he speaks to us today. ${ }^{41}$ If this spiritual formation is lacking, then it would be very easy to lose our patience if we pray and do not receive what we have asked for, thus limiting ourselves to prayer as simple petition. Distractions are part and parcel with prayer. Being human, we cannot eliminate distractions completely. However, we can address them in our prayers and pray with, and through them. This is also a matter which needs to be considered during the process of catechesis. ${ }^{42}$

The process of catechesis itself offers many ways in which spiritual formation through prayer does not remain simple technical knowledge and information. Spiritual formation through prayer in catechesis can be experienced in a physical way through short moments of prayer at the beginning and at the end of the meetings. These short moments of prayer which are well-prepared demonstrate the faith of those who are in prayer, while also showing that to pray, one needs to prepare oneself well before, and not just stop whatever one is doing and pray. One can also have a prayer meeting during specific moments of catechesis. Here, many more symbolic actions can be used such as candles, setting up the Bible in a central position, dimmed lights, sitting posture, and so on.

A prayer method which is constantly gaining ground is the biblical method of prayer though Lectio Divina. The Lectio Divina method is a simple method in successive steps through which the interlocutors are guided to read, meditate, reflect, contemplate and apply the Word of God to their daily life situations. ${ }^{43}$

${ }^{39}$ Cfr. The Six Tasks of Catechesis, p. 49.

${ }^{40}$ Cfr. B. Singer-Towns (ed.), The Catholic Faith Handbook for Youth, Winona 2008, Saint Mary's Press, Christian Brothers Publications, p. 314-321.

${ }^{41}$ Cfr. The Catholic Faith Handbook for Youth, p. 306-311.

${ }^{42}$ Cfr. The Six Tasks of Catechesis, p. 50.

${ }^{43}$ Cfr. The Catholic Faith Handbook for Youth, p. 337-339; The Six Tasks of Catechesis, p. 52. 
This method helps the individual to know the Word of God and to apply it and live it in daily life. This ultimately results in living one's faith in a coherent way in the different events of life, be it when they are young, and when they mature through life. It is an application of the Word of God to one's actual life situation.

\section{Moral Formation}

The person who finds a treasure in life seeks to live what that treasure entails. Likewise, the believer who has found out about Christ and about the way which Christ has shown us as the lifestyle of the Christian, seeks to live the implications of this lifestyle. The living out of the implications of the way of Christ which we find in the Gospels is achieved after one has gone through a thorough moral formation. This is why one of the tasks of catechesis constitutes the moral formation of the Christian. ${ }^{44}$

Moral formation has to do with living the Gospels in our everyday life. This in actual fact is very closely linked to the choices and the decisions which we as individuals make. In this aspect, the Word of God in the Bible is the primary and sine-qua-non source for moral formation. ${ }^{45}$ The choices which we make are the front-office and the direct reflection of what we believe, since it is through them that others can get a glimpse and an access to what we believe. This is akin to witness in the daily life of the Christian which in our contemporary times speaks louder than words. ${ }^{46}$

Moral formation is aimed at the formation of the conscience of the individual, since it is when the human being has a truly formed conscience that $\mathrm{s} / \mathrm{he}$ can make correct and informed decisions. The conscience is the inner voice deep within the person which drives him/her to choose what is good and to avoid all that is evil. The conscience is God's inner voice in our hearts. The formation of the conscience of the individual is a very important task in our contemporary times when there seem to be no clear distinction between what is right and what is wrong, and in a society which seeks to evaluate all things from the utilitarian and hedonistic points of view in relation to the individual concerned. ${ }^{47}$

\footnotetext{
${ }^{44}$ Cfr. General Directory for Catechesis, para. $85 \$$ Moral formation.

${ }^{45}$ Cfr. The Six Tasks of Catechesis, p. 38.

${ }^{46}$ Cfr. Evangelii Nuntiandi, para. 21-26, 41.

${ }^{47}$ Cfr. The Six Tasks of Catechesis, p. 37, 39.
} 
The moral formation in catechesis should also seek to highlight the importance of acknowledging that since we are all human, we all make mistakes at some time or another. This means that since nobody is perfect, we must be able to forgive each other just as God forgives us as we pray in the Our Father. This forgiveness which we offer to each other is another aspect of humanity which should become an attitude in believers. It is not something which we do for a limited amount of times; it should become a part of our everyday life. In this aspect, through catechesis we are called to be merciful just as our Father in heaven is merciful $(\mathrm{Lk} 6,36){ }^{48}$

Through moral formation, we are called to extend our experience of God's mercy towards us to others, whose actions beg for our mercy. When we go through an experience of God's mercy and forgiveness, we feel satisfied, at ease, in peace and spiritually fit. When we offer mercy to others who have in some way erred on our behalf, we help them to undergo the same experience of tranquillity and spiritual well-being by offering them our mercy and forgiveness.

Moral formation helps the individual to be authentic. Authenticity is the mark of the Christian believer. One of the most efficacious ways of helping others to edify themselves through moral formation is by presenting role models and case studies. ${ }^{49}$ In these last years, we as Catholics, together with people from other denominations and beliefs have been experiencing a very particular phenomenon where Pope Francis is concerned. Pope Francis seems to be an attraction to all those who happen to follow him or to encounter him in some way or another. Many people enquire about what is the phenomenon which makes him so attractive on a human level to people of all faiths and beliefs. A very plausible answer to this enquiry is the fact that Pope Francis is an authentic believer. He does not speak and teach about how the believer should live his/ her life, but he actually lives that life-style himself beforehand. This makes his witness very powerful, and at the same time attractive to the people in this day and age where authenticity does not feature much in our society even on a human level. In this sense, Pope Francis is a model and also a source of data for case studies which can help our interlocutors to grow in their moral life. Besides, Pope Francis, who is a living icon, the lives of the saints can play a very important role in catechesis which aims to give a sound moral formation in our contemporary times.

${ }^{48}$ Cfr. The Six Tasks of Catechesis, p. 39.

${ }^{49}$ Cfr. The Six Tasks of Catechesis, p. 42. 


\section{Education for Life in the Community}

One of the most famous lines of the English poet John Donne states that "no man is an island." This has been and still is so true. One of the common features of all human beings of whatever age and race is that they are called to live in relationships with each other. These relationships can be of different kinds and intensities. The believing community fosters a particular type of relationship which is not strictly linked to sympathy or to some form of human love, or to blood relations. The believers in Jesus Christ are bound together and united because they share common values, centred around the life style and the teachings of Jesus which are found in the Gospels. ${ }^{50}$ Fostering a community which is based on love is one of the fundamental tasks of catechesis.

In our day and age, where relationships are being moved from the real world to the virtual world, the value of a community of believers who live and practice their faith together is all the more necessary. We were created social beings, but communion does not only have an impact on our social life. It is necessary to support each other and to be truly sensitive to the needs of others during our walk of life. Today, it is very easy to simply take care of your tasks and needs, while totally forgetting that around us there are others who are crying out for help. Catechesis renders the individual conscious of the needs of others not only by teaching us about how we can truly live as a community of believers and meet each other on the day of the Lord, but it also helps the interlocutors to make first hand experiences of diakonia. ${ }^{51}$

We are also living in a world which seems to be constantly grappling and divided through multiple divisions not only among different nations and people, but at times even within the same family. This should act as a catalyst for catechesis' role in educating people for community life. Catechesis in this sense seeks to shed more light on what it means to live in a peaceful world, and how one can in real fact foster more peaceful attitudes through choices. Of particular significance is the relationship of catechesis to the political world, where those who are Christians and at the same time decide to enter into the political arena are called to serve the world through the building up of a more just world, based

${ }^{50}$ Cfr. The Six Tasks of Catechesis, p. 59.

${ }^{51}$ Cfr. La catechesi oggi, p. 202-208; Communicating a Faith that Transforms, p. 191-196; E. Alberich, Catechesi, diakonia e impegno nella società, in: Istituto di Catechetica. Facoltà di Scienze dell'Educazione, Università Pontificia Salesiana - Roma (ed.), Andate e insegnate. Manuale di catechetica, Leumann (Torino) 2002, Elledici, p. 128-134. 
on equity where all have access to basic resources. Moreover, the believers involved in the political world have a bigger responsibility in working for peace and harmony throughout the world. ${ }^{52}$

The reason why catechesis is organised in small groups is not an arbitrary or insignificant one. The Catholic Church is not simply made up of individuals who believe in Jesus Christ personally. The Catholic Church is a call to be a community. This is the reason why catechesis is actually done in small groups, be it catechesis for Christian Initiation or permanent formation. Probably it would be much easier for individuals had they to be given a book or different texts and to go through them at their own pace in the comfort of their homes, but catechesis has a communitarian dimension which is necessary. The dynamics of the group have a very important role because it helps the interlocutors to socialise and to grow together as a community and not simply individually.

The communitarian dimension of catechesis is also one of the focal points of any catechesis for Christian Initiation. In Christian Initiation, the interlocutor who is seeking to become a member of the Christian community is not only given a set of guidelines or principles on which the community is founded, but $\mathrm{s} /$ he is actually introduced to community life in a gradual manner. This means experiencing the real life of the community from within in the form of an apprenticeship, with all the ups and downs which a community faces in the contemporary world. ${ }^{53}$

The world in which we are living is no longer homogenous in its beliefs. We can say that the society in which we are living is no longer related to Christendom, which is considered today as a thing of the distant past. This undoubtedly calls the contemporary human being to live alongside with others who have different beliefs and different forms of expression for their beliefs. This is the reason why the task of catechesis in educating for community life cannot do without an ecumenical dimension. ${ }^{54}$ The ecumenical dimension is not intended to proselytise in favour of the Catholic religion, but it is a sensibility and an openness to the richness of other faiths and beliefs. ${ }^{55}$ In this respect, the

52 Cfr. La catechesi oggi, p. 213-220; Communicating a Faith that Transforms, p. 200-206.

${ }^{53}$ Cfr. P. Braud, Il vissuto autentico della comunità cristiana, vero luogo d'iniziazione, in: H. Derroitte (ed.), Catechesi e iniziazione cristiana, Leumann (Torino) 2006, Elledici, p. 85-97.

${ }^{54}$ Cfr. General Directory for Catechesis, para. $86 \$$ Education for Community Life.

${ }_{55}$ Cfr. La catechesi oggi, p. 230-238; Communicating a Faith that Transforms, p. 219-227. 
Catholic Social Teaching of the Church plays a primary role in forming individuals in the way in which St John Bosco wanted: good Christians, honest citizens. ${ }^{56}$

\section{Missionary Initiation}

The final task of the process of catechesis entails initiating the faithful to a missionary life style. The idea of embarking on a mission may be somewhat confusing to many people since many people think that missionary activity is linked directly to the mission lands. In this respect, catechesis does not intend missionary activity in the way it was understood before Vatican Council II, where all missionary activity was linked to mission lands and to the proclamation of the Gospel to those who had never heard of Christ in foreign lands. Here, missionary initiation refers to being a witness in one's daily life, and not to the process of leaving one's homeland and going abroad to evangelise foreign nations. ${ }^{57}$

The believer who through catechesis gets to know Christ is called to bear witness to him though daily life and not just when s/he is in church or in ecclesiastical circles. Being Christian means bearing witness to what one believes through words, deeds and choices which may not be strictly linked to the life of faith. Here, we enter a new dimension of what missionary initiation means: bearing witness through acts and deeds.

The fact that the society in which we are living is no longer a homogeneous society, and it is no longer Christian in its basic fabric as it was in the past means that it is no longer easy and straightforward to live one's faith as it was before since society may be indifferent or hostile to Christian values. On the contrary, today, anybody seeking to live one's faith in a coherent way needs to work against the current through actions, deeds and choices. It is precisely though these words, deeds and choices that the faithful are called to be leaven in contemporary society, transforming it silently from within. Without saying anything, their effect will be felt as leaven acting silently in dough.

Authenticity is the keyword which highlights this witness which all the believers are called to live. The one and only model for authenticity is Jesus himself, whom the crowds believed because "he taught them as one having authority, and not as the scribes" (Mk 1,22). This authority was the result of the coherent and

\footnotetext{
${ }^{56}$ Cfr http://www.sdb.org/en/ (31.10.2017).

${ }^{57}$ Cfr. General Directory for Catechesis, para. $86 \$$ Missionary initiation.
} 
authentic life which Jesus openly lived. He never said one thing and then acted in another way. Jesus never gave contradictory messages, but what he preached he was already living beforehand. This is the way in which both catechists and the lay faithful are called to live their faith.

In our contemporary society, it is becoming more common to have people who either sit at the periphery of whatever is happening, or to take a passive attitude in whatever is happening. Others even venture to consider faith and the expression of their faith as a service station for their particular needs. These are some of the negative attitudes which catechesis attempts at overcoming through the task of missionary initiation. Whoever forms part of the Church of Christ is not called to simply sit and support from a distance, but s/he is called to enter the playground and contribute to the good and the well-being of others. This is achieved in a specific way through diakonia. In fact, missionary initiation in the Church is usually transformed into myriad forms of diakonia and of service to the most vulnerable. ${ }^{58}$ These different forms of diakonia reach their summit in the different vocations with which the faithful are called to serve others in life, be it a priestly vocation, or through the Sacrament of Marriage or through consecrated life.

One of the greatest difficulties which the contemporary human being is encountering at different levels and in different ways in life is that of interpersonal communication. Although we have many gadgets which help us to communicate instantaneously, we seem to be gradually forgetting how to communicate with others in an effective way. Communication seems to be more dominated by tones of domination and of a top-down approach. This results in a monologue rather than in a dialogue. Missionary initiation, being one of the tasks of catechesis, also induces the believer to enter into interreligious dialogue with people who adhere to different faiths and denominations. The underlying reason for this is not to convert the other person, but to be enable a constructive dialogue

${ }^{58}$ Cfr. La catechesi oggi, p. 208-213; Communicating a Faith that Transforms, p. 196-200; E. Alberich, Catechesi ecumenica, in: Istituto di Catechetica. Facoltà di Scienze dell'Educazione, Università Pontificia Salesiana - Roma (ed.), Andate e insegnate. Manuale di catechetica, Leumann (Torino) 2002, Elledici, p. 134-139; C. De Souza, Catechesi e pluralismo culturale e religioso, in: Istituto di Catechetica. Facoltà di Scienze dell'Educazione, Università Pontificia Salesiana - Roma (ed.), Andate e insegnate. Manuale di catechetica, Leumann (Torino) 2002, Elledici, p. 142-143, 146-148. 
through which both parties, while retaining their particular faith and beliefs, emerge richer by understanding the other person and his/her beliefs better. ${ }^{59}$

\section{Conclusion}

The six tasks of catechesis demonstrate the extent of the Church's mission of evangelisation. Undoubtedly, the tasks clearly show the need that catechists needs to be well-trained and formed in order to achieve good results. Catechesis is a ministry for which a basic and an on-going formation are thoroughly needed. If the formation of catechists is not taken seriously, these different tasks will not be achieved in a balanced and coherent way. It is only through formation in 'being', in 'knowing' and in 'knowing how to' that catechists will be flexible enough to adapt themselves to transmit the Gospel message for which they are only stewards and ambassadors. ${ }^{60}$

This demonstrates that for catechesis to successfully deliver the six tasks entrusted to its care, the catechist must consider his/her ministry as a vocation. Pope Francis envisages that the catechist's ministry is a vocation, and that catechists are called "...not to 'work' as catechists: this will not do. I work as a catechist because I like to teach... But unless you 'are' a catechist, it is no good! You will not be successful ... you will not bear fruit! Catechesis is a vocation: 'being a catechist'..."

Catechists are human beings. As human beings, our natural tendency is to evaluate the ministry of catechesis through the visible results achieved. However,

59 Cfr. La catechesi oggi, p. 160-161, 188-191; Communicating a Faith that Transforms, p. 151-153, 180-183.

${ }^{60}$ Cfr. C. Bissoli, J. Gevaert (eds.), La formazione dei catechisti. Problemi di oggi per la catechesi di domani, Leumann (Torino) 1998, Elledici; S. Calabrese (ed.), Catechesi e formazione. Verso quale formazione a servizio della fede?, Leumann (Torino) 2004, Elledici; G. Morante, I catechisti: identità e formazione, in: Istituto di Catechetica. Facoltà di Scienze dell'Educazione, Università Pontificia Salesiana - Roma (ed.), Andate e insegnate. Manuale di catechetica, Leumann (Torino) 2002, Elledici, p. 334-336; J. Dunlap, Practical Catechesis. Visions and Tasks for Catechetical Leaders, Cincinnati, Ohio - 2001, St. Anthony Messenger Press, 169-172, 201-207.

61 Pope Francis, Address of the Holy Father Francis to Participants in the Pilgrimage of Catechists on the Occasion of the Year of Faith and of the International Congress on Catechesis (27th September 2013), https://w2.vatican.va/content/francesco/en/speeches/2013/september/ documents/papa-francesco_20130927_pellegrinaggio-catechisti.html (1.11.2017). 
one must constantly keep in mind that the fruits of catechesis which are the visible end result of the endeavours of the catechist in trying to achieve these six tasks in a satisfactory manner may take time, and may not be evidently visible even after a long time.

\section{Bibliography}

Alberich E., La catechesi oggi. Manuale di catechetica fondamentale, Leumann (Torino) 2001, Elledici.

Alberich E., J. Vallabaraj, Communicating a Faith that Transforms. A Handbook of Fundamental Catechetics, Bangalore 2004, Kristu Jyoti Publications.

Biancardi G., U. Gianetto, Storia della catechesi. 4. Il movimento catechistico, Roma 2016.

Biernatzki W. E., Catholic Communication Research. Topics and a Rationale, London 1978, The Research Facilitator Unit for Social Communication.

Bissoli C., Va' e annuncia (Mc 5, 19). Manuale di catechesi biblica, Leumann (Torino) 2006, Elledici.

Bissoli C., J. Gevaert (eds.), La formazione dei catechisti. Problemi di oggi per la catechesi di domani, Leumann (Torino) 1998, Elledici.

Calabrese S. (ed.), Catechesi e formazione. Verso quale formazione a servizio della fede?, Leumann (Torino) 2004, Elledici.

Derroitte H. (ed.), Catechesi e iniziazione cristiana, Leumann (Torino) 2006, Elledici.

Dunlap J., Practical Catechesis. Visions and Tasks for Catechetical Leaders, Cincinnati, Ohio - 2001, St. Anthony Messenger Press.

Glavich M. K., The Six Tasks of Catechesis. Key Principles and Practices for Forming Faith, New London 2016, Twenty-Third Publications.

Istituto di Catechetica. Facoltà di Scienze dell'Educazione, Università Pontificia Salesiana - Roma (ed.), Andate e insegnate. Manuale di catechetica, Leumann (Torino) 2002, Elledici.

Pope Benedict XVI, Angelus - Sunday $24^{\text {th }}$ October 2010, http://w2.vatican.va/content/ benedict-xvi/en/angelus/2010/documents/hf_ben-xvi_ang_20101024.html (21.09.2017).

Pope Francis, Address of the Holy Father Francis to Participants in the Pilgrimage of Catechists on the Occasion of the Year of Faith and of the International Congress on Catechesis (27 ${ }^{\text {th }}$ September 2013), https://w2.vatican.va/content/francesco/en/ speeches/2013/september/documents/papa-francesco_20130927_pellegrinaggiocatechisti.html (1.11.2017).

Pope Francis, Address to the Members of the Representative Council and Personnel of "Caritas Internationalis" - $17^{\text {th }}$ November 2016, http://w2.vatican.va/content/ francesco/en/speeches/2016/november/documents/papa-francesco_20161117_caritasinternationalis.html (21.09.2017). 
Pope Francis, Evangelii Gaudium (24 ${ }^{\text {th }}$ November 2013), http://w2.vatican.va/content/francesco/en/apost_exhortations/documents/papa-francesco_esortazioneap_20131124_evangelii-gaudium.html (5.10.2017).

Pope Paul VI, Evangelii Nuntiandi ( $8^{\text {th }}$ December 1975), http://w2.vatican.va/content/ paul-vi/en/apost_exhortations/documents/hf_p-vi_exh_19751208_evangeliinuntiandi.html (19.09.2017).

Sacred Congregation for the Clergy, General Catechetical Directory (11 ${ }^{\text {th }}$ April 1971), http://www.vatican.va/roman_curia/congregations/cclergy/documents/rc_con_cclergy_ doc_11041971_gcat_en.html (23.09.2017], para. 31; General Directory for Catechesis.

Singer-Towns B. (ed.), The Catholic Faith Handbook for Youth, Winona 2008, Saint Mary's Press, Christian Brothers Publications.

Sultana C. M. Sultana, Catechesis in Europe during the 20th Century, in: G. Bonney, R. Vicent (eds.), Sophia - Paideia. Sapienza e educazione (Sir 1, 27). Miscellanea di studi offerti in onore del prof. Mario Cimosa, Roma 2012, LAS, p. 423-450.

Vatican Council II, Constitution on the Sacred Liturgy Sacrosanctum Concilium $\left(4^{\text {th }}\right.$ December 1963), http://www.vatican.va/archive/hist_councils/ii_vatican_council/ documents/vat-ii_const_19631204_sacrosanctum-concilium_en.html (11.10.2017). 